\title{
Impact of Admitted Student Programs on Matriculation and Retention
}

\author{
Tara M. King and Roger D. Wessel
}

When addressing transitional programming for admitted students, Perigo and Upcraft (1989) indicated that the "critical components of these programs are the increased time with continuing students, time to interact with the campus environment, including residence-hall visits, sitting in on actual classes, and department or program-level individual appointments" (p. 87). All of these components were offered through special programs for admitted students in the spring semester of 2000 by the Office of Orientation and New Student Programs at a Midwestern, public, mid-size, doctoral-intensive institution. The purpose of this study was to determine if program participants in admitted student programs matriculated and persisted at greater rates than admitted students who did not participate in admitted student programs.

In the past, the recruitment funnel was concerned primarily with increasing enrollment through the recruitment of new students. Tinto and Wallace (1986) wrote, "many academic officials believe the survival of their institution depends on maintaining, if not increasing, college enrollments. As a result, most institutions have adopted the obvious strategy: emphasizing recruitment" (p. 290). However, the number of students leaving college without completing degrees also has a negative impact on enrollment. Retention is important because

it builds stability into a university system. With a high and constant rate of retention, universities can expand their benefits and their offerings, thereby enhancing student interest and further stabilizing the institution. A low and inconsistent retention rate creates a system of uncertainty (Cambiano, Denny, \& DeVore, 2000, p. 28).

An effective orientation has been found to be a major contributor to matriculation, retention, and enrollment management. Orientation has been defined as any effort to help first-year students enhance success and make the transition from their previous environments to the collegiate environment (Perigo \& Upcraft, 1989). "There is evidence that participation in orientation activities can result in better academic achievement and higher retention than nonparticipation" (Upcraft, 1984, p. 107). Pascarella (1985) also argued that student participation in orientation had a positive effect on persistence.

Upcraft and Farnsworth (1984) discussed several goals of orientation, including the academic and personal transition to college. Tinto (1993) noted that transition was "a

Tara M. King is the Assistant Director of the Career Center at Ball State University in Muncie, Indiana, where Roger D. Wessel is the Assistant Vice President for Planning, Research, and Evaluation in the Division of Student Affairs and Enrollment Management and an Assistant Professor of Higher Education. 
period of passage between the old and the new, before the adoption of new norms and patterns of behavior and after the onset of separation from old ones" (p. 97). Tinto (1987) specifically noted that orientation programs narrowed the gap between the institutions and students expectations and needs.

Orientation programs have also been depicted as a form of anticipatory socialization where individuals come to anticipate correctly the values, norms, and behaviors they will encounter in a new social setting. Pascarella, Terenzini, and Wolfe (1986) noted that "the stronger the individual's level of social and academic integration, the greater his or her subsequent commitment to the institution and to the goal of college graduation" (p. 155-156). The need for social and academic integration can also be explained as a need for a student to fit with an environment.

There are three primary subcategories of orientation activities. According to Perigo and Upcraft (1989)

the first phase is preadmissions, which includes informing prospective students about the institution through campus visitation and written materials. The second phase is pre-enrollment, which includes summer programs for freshmen. The third phase is initial enrollment, including those programs just before the start of classes and throughout the first semester (p. 85).

During all three phases transitional issues are addressed and informed decisions are encouraged to help students determine if they "fit" with a particular college environment.

Many authors have written about the importance of person-environment fit on persistence and retention. Lenning, Sauer, and Beal (1980) defined "student-institution fit" as "moral and social integration, perceived responsiveness of the institution to student needs, and the congruence between expectations and opportunities for their realization" (p. 3). Beal and Noel (1980) wrote "retention research today emphasizes the importance of the interaction between student and the institution...the degree of fit may determine the likelihood of staying or leaving. Another term, which may describe it better, is belonging" (p. 5). Twale (1989) extended that idea, indicating that "visual perception, initial interaction, and first impressions play a significant role in guiding a student's future direction. A new student therefore needs to acclimate to the new environment in order to bridge the gap caused by the imposed anonymity of campus life" (p. 161).

\section{Special Programs for Admitted Students}

The Office of Orientation and New Student Programs at a Midwestern, public, midsize, doctoral-intensive institution offered special programs for admitted students in the spring semester of 2000. Students who participated in these admitted student programs (pre-enrollment programs as defined by Perigo and Upcraft, 1989) had already been recruited and accepted to the institution. Therefore, the purpose of these programs was to foster admitted student commitment and matriculation to the institution, and to 
help admitted students make informed decisions about attending the institution, thus increasing student persistence. This was communicated to admitted students through the program invitation.

Many students apply to not just one, but several colleges or universities. If you have been admitted to more than one school, you should make an informed decision about which school to attend. Choosing the college or university that best suits your specific needs is an important step, and the best way to decide which school is right for you is to visit campuses you are considering (Office of Orientation and New Student Programs, 2000).

The programs allowed admitted students and their family members to experience the campus environment, meet faculty, staff, and current students, and receive answers to questions concerning admission, orientation, and collegiate life. The following three admitted student programs were offered in the spring of 2000.

Cardinal Success Seminars. Half-day programs where admitted students and family members participated in an interactive campus visit, became involved in a classroom experience, attended a seminar on how to be successful in college, had lunch with a current student host in a campus dining facility, and toured a residence hall.

Student for a Day. Day-and-a-half programs where admitted students stayed overnight with a student host in a residence hall, participated in a residence hall social activity, ate in campus dining facilities, attended two college classes, and met with a current student panel for a question and answer session.

Cardinal Basketball. Half-day programs where admitted students and their family members met athletic and recreation programs staff, toured campus athletic and recreation facilities, ate in a campus dining facility, and attended an intercollegiate basketball game.

The extent that these three programs were important in the admissions funnel and the effect they had on college selection, student transition, and institutional retention were important to identify. The current study sought to answer the following question. Did admitted students who participated in admitted student programs (pre-enrollment programs as defined by Perigo and Upcraft, 1989) matriculate and persist into the second semester of study at greater rates than students who did not participate in admitted student programs?

\section{Research Method}

\section{Population and Sample}

The population for this study was 7,384 students admitted to the institution for the fall semester of 2000. The sample equaled the population $(n=7,384)$. To answer the research question, four sub-groups were defined from the population, and three were used in data analysis. The first sub-group consisted of 378 admitted students who had 
attended an admitted student program during the spring semester of 2000. The second sub-group consisted of 2,206 admitted students who had attended an on-campus admissions program. The on-campus admissions programs would be categorized as pre-admission programs as defined by Perigo and Upcraft (1989) and they included general admissions presentations, campus tours, and meetings with faculty if requested by the student. The third sub-group defined in this study consisted of 4,571 admitted students who had not attended an admitted student program or an on-campus admissions program. A fourth sub-group, consisting of 229 admitted students who had attended both an admitted student program and on-campus admissions program, was eliminated from this study so that a clear comparison could be made between participants in admitted student programs and on-campus admission programs. Data were collected from university databases that contained information on all admitted students including their participation in programs before matriculation and their persistence into the spring semester, as the associations between variables were sought using a chi-square analysis.

\section{Results}

\section{Profile of Participants}

Admitted students who participated in an admitted student program during the spring semester of 2000 consisted of $62.4 \%$ (379) females and $37.6 \%$ (228) males. Indiana residents made up $80.2 \%$ (487) of the participants, $16.3 \%$ of participants came from contiguous states, and 3.5\% were from other states. Slightly more than 22\% (135) were admitted with honors, $22.9 \%$ (139) were admitted with distinction, and 54.9\% (333) had regular admission status. Caucasian students made up 93.2\% (566) of the participants, $2.8 \%$ (17) were African-American, and 1.5\% (9) were Hispanic. The participants in admitted student programs were similar to student participants in the admissions programs.

\section{Matriculation}

The matriculation rate of students was compared between students who attended admitted student programs versus those who had attended on-campus admissions programs. Slightly more than $73 \%$ of students who participated in an admitted student program matriculated (Table 1). Fifty-nine percent of students who attended an oncampus admissions program matriculated. A statistically significant difference $\left(\mathrm{X}^{2}(1, \mathrm{~N}=2,584)=27.6, \mathrm{p}<.001\right)$ existed between the two groups. Students who attended admitted student programs matriculated at a greater rate than students who attended on-campus admissions programs.

The matriculation rate of students was also compared between students who attended admitted student programs versus those who did not attend an admitted student program or an on-campus admissions program. Nearly $43 \%$ of students who attended neither program matriculated. A statistically significant difference $\left(\mathrm{X}^{2}(1\right.$, 
$\mathrm{N}=4,949)=131.5, \mathrm{p}<.001$ ) existed between the two groups. Students who participated in an admitted student program matriculated at a greater rate than those students who attended neither program.

\section{Persistence}

Of those admitted students who matriculated to the university in the fall of 2000 , not all persisted to the second semester of study. The persistence rate of students who attended an admitted student program was compared to the persistence rate of students who attended an on-campus admissions program. Nearly $94 \%$ of students who attended an admitted student program persisted to the second semester (see Table 2). Slightly more than $93 \%$ of students who attended an on-campus admissions program persisted. No significant difference $\left(\mathrm{X}^{2}(1, \mathrm{~N}=1,579)=.217, \mathrm{p}=.641\right)$ was found between the two groups. Students who attended an admitted student program persisted at the same rate as students who attended an admissions program.

The persistence rate of students was also compared between students who attended an admitted student program versus students who did not attend an admitted student program or an on-campus admissions program. Students who attended neither program persisted at a rate of $77.5 \%$. A statistically significant difference $\left(X^{2}(1, N=2,231)=39.8\right.$, $\mathrm{p}<.001)$ existed between the two groups. Students who attended an admitted student program persisted at a greater rate than students who attended neither program.

\section{Discussion}

Programs specifically designed for admitted students are valuable because they may help students finalize their college enrollment decision. Students who attend admitted student programs matriculate at a greater rate than students who attend on-campus admissions programs and students who attend no campus-based programs. Admitted student programs provide participants with personal attention, and they allow participants to get a "feel" for the university and become more comfortable with the environment. This was supported by written comments on the student evaluations from each program. Cardinal Success Seminar participants said the program "tried to accommodate everyone's interests," and smaller group sizes allowed for better interaction. Student for a Day participants said they liked the opportunity to have close interaction with students. "This was much more personal than preview days and stuff," commented one student. Another student said, "what I liked the most was getting to stay with a host in which I met new people and got shown around campus," while another enjoyed "the chance to interact with students in their own environment." Admitted student program participants are more likely to feel connected to the university, may feel more secure with their ability to "fit" in the collegiate environment, and thus may be more likely to enroll in the fall.

Admitted student program participants are more likely to persist into the second semester of study than students who do not visit the campus for admissions or admitted 
student programs. Students who participate in admitted student programs have a meaningful campus visit including attending a university class, meeting current students, and spending the night in a residence hall. Having these experiences prior to matriculation may mean that participants require less time to adjust to the college environment leading to higher persistence. One Student for a Day participant enjoyed "getting to experience college before hand so I knew what to expect," while another said the program "gets you comfortable with the idea of college." Participants said they had the chance to feel like a real student, usually through the classroom experience or through staying in the residence hall. Cardinal Success Seminar participants said they liked "being able to sit in a class so you know how college really is." Students who attended Student for a Day liked the residence hall experience. "I think it's a wonderful way to get to know student life," said one student, while other students said they enjoyed feeling a sense of "independence" and the chance to "experience an actual day as a student on your own." Students who participate in admitted student programs may know whether they fit into a collegiate environment prior to enrollment as opposed to students who do not attend programs and find that the university is not a fit for them after they have already matriculated.

Colleges and universities should consider including these programs for admitted students in their recruiting funnel because they help students make a more informed college decision, develop a greater commitment to the institution, and may make them more likely to enroll. College and universities should consider allocating adequate resources to these programs, as they may be a valuable addition to their retention-based programming.

Many factors that can influence matriculation decisions and student persistence, for example, family income and support, were not controlled in this study. Unidentified variables may have affected matriculation and persistence. Also, this study reflects the findings at one university. Results may vary based on the type, size, location, and demographics of the institution providing an admitted student program.

More research on admitted student programs and their impact on student matriculation and persistence is needed. Researchers should study the progress of program participants to see if they persist to the sophomore, junior, and senior years at greater rates than students who do not participate in admitted student programs. In addition, participants should be asked how their participation in these programs weighed on their decision to matriculate to the university and their ability to succeed in college.

\section{References}

Beal, P. E., \& Noel, L. (1980). What works in student retention? Iowa City, IA: American College Testing Program and National Center for Higher Education Management Systems.

Cambiano, R. L., Denny, G., \& DeVore, J. (2000). College student retention at a midwestern university: A six-year study. The Journal of College Admission, 166, 22-29. 
Lenning, O. T., Sauer, K., \& Beal, P. E. (1980). Student retention strategies.

AAHE-ERIC/Higher Education Research Report, 8. Washington, DC: American Association for Higher Education.

Office of Orientation and New Student Programs. (2000). Finalize your college choice [Brochure]. Muncie, IN: Ball State University.

Pascarella, E. T., Terenzini, P. T., \& Wolfe, L. M. (1986). Orientation to college and freshman year persistence/withdraw decisions. Journal of Higher Education, 57, 155-175.

Perigo, D. J., \& Upcraft, M. L. (1989). Orientation programs. In M. L. Upcraft, J. N. Gardner, \& Associates (Eds.), The Freshman Year Experience (pp. 82-94). San Francisco: Jossey-Bass.

Tinto, V. (1987). Leaving college: Rethinking the causes and cures of student attrition research. Chicago: University of Chicago.

Tinto, V. (1993). Leaving college: Rethinking the causes and cures of student attrition research (2nd ed.). Chicago: University of Chicago.

Tinto, V., \& Wallace, D. L. (1986). Retention: An admission concern. College and University, 61, 290-293.

Twale, D. J. (1989). Social and academic development in freshman orientation: A time frame. NASPA Journal, 27, 160-166.

Upcraft, M. L. (1984). Orientation programs: Myths and realities. In M. L. Upcraft (Ed.), Orienting Students to College (pp. 107-109). San Francisco: Jossey-Bass.

Upcraft, M. L., \& Farnsworth, W. M. (1984). Orientation programs and activities. In M. L. Upcraft (Ed.), Orienting Students to College (pp. 27-38). San Francisco: JosseyBass. 


\begin{tabular}{|c|c|c|c|c|}
\hline \multirow[t]{2}{*}{ Program } & & \multicolumn{3}{|c|}{ Did Student Matriculate? } \\
\hline & & No & Yes & Total \\
\hline \multirow[t]{2}{*}{ Attended Admitted Student Program } & $\underline{\mathrm{n}}$ & 101 & 277 & 378 \\
\hline & $\%$ & 26.7 & 73.3 & 100.0 \\
\hline Attended On-Campus Admission & $\underline{\mathrm{n}}$ & 904 & 1302 & 2206 \\
\hline Program a & $\%$ & 41.0 & 59.0 & 100.0 \\
\hline \multirow[t]{2}{*}{ Attended Neither Program ${ }^{b}$} & $\underline{\mathrm{n}}$ & 2617 & 1954 & 4571 \\
\hline & $\%$ & 57.3 & 42.7 & 100.0 \\
\hline
\end{tabular}

\section{Notes}

a Comparison of admitted student programs verses on-campus admission programs $\mathrm{X}^{2}(1, \mathrm{~N}=2,584)=27.6, \mathrm{p}<.001$

b Comparison of admitted student programs verses attended neither program $\mathrm{X}^{2}(1, \mathrm{~N}=4,949)=131.5, \mathrm{p}<.001$

\section{TABLE 2}

\section{Persistence Rates of Students Participating in Admitted Student Programs, On-campus Admissions Programs, and Neither Program}

\begin{tabular}{|c|c|c|c|c|c|}
\hline \multirow[t]{2}{*}{ Program } & & \multicolumn{4}{|c|}{ Did Student Persist? } \\
\hline & & No & & Yes & Total \\
\hline \multirow[t]{2}{*}{ Attended Admitted Student Program } & $\underline{\mathrm{n}}$ & 17 & & 260 & 277 \\
\hline & $\%$ & 6.1 & & 93.9 & 100.0 \\
\hline Attended On-Campus Admission & $\underline{\mathrm{n}}$ & 90 & & 1212 & 1302 \\
\hline Program a $^{a}$ & $\%$ & 6.9 & & 93.1 & 100.0 \\
\hline \multirow[t]{2}{*}{ Attended Neither Program ${ }^{b}$} & $\underline{\mathrm{n}}$ & 439 & & 1515 & \multirow[t]{2}{*}{1954} \\
\hline & $\%$ & 22.5 & 77.5 & 100.0 & \\
\hline
\end{tabular}

\section{Notes}

a Comparison of admitted student programs verses on-campus admission programs $\mathrm{X}^{2}(1, \mathrm{~N}=1,579)=.217, \mathrm{p}=.641$

b Comparison of admitted student programs verses attended neither program $\mathrm{X}^{2}(1, \mathrm{~N}=2,231)=39.8, \mathrm{p}<.001$ 